\title{
Landfill sites selection using MCDM and comparing method of change detection for Babylon Governorate, Iraq
}

\author{
Ali Chabuk ${ }^{1,2} \cdot$ Nadhir Al-Ansari ${ }^{1}$ (D) Hussain Musa Hussain ${ }^{3} \cdot$ Jan Laue $^{1} \cdot$ Anwer Hazim $^{4} \cdot$ Sven Knutsson $^{1}$. \\ Roland Pusch ${ }^{1}$
}

Received: 19 October 2018 / Accepted: 2 April 2019 / Published online: 1 May 2019

(C) The Author(s) 2019

\begin{abstract}
Landfill site's selection represents a complicated process due to the large number of variables to be adopted. In this study, an arid area (Babylon Governorate as a case study) was selected. It is located in the middle region of Iraq. In this area, the landfills do not satisfy the required international criteria. Fifteen of the most significant criteria were selected for this purpose. For suitable weight for each criterion, the multi-criteria decision-making (MCDM) methods were applied. These methods are AHP and RSW. In the GIS software 10.5, the raster maps of the chosen criterion were arranged and analyzed. The method of change detection was implemented to determine the matching pixels and non-matching pixels. The final results showed that there are two candidate locations for landfills for each district in the governorate (ten sites). The areas of the selected sites were sufficient to contain the cumulative quantity of solid waste from 2020 until 2030.
\end{abstract}

Keywords MCDM $\cdot$ Change detection $\cdot \mathrm{RSW} \cdot \mathrm{AHP} \cdot$ Landfill siting

Responsible editor: Philippe Garrigues

Nadhir Al-Ansari

nadhir.alansari@1tu.se

Ali Chabuk

ali.chabuk@1tu.se; ali_chabuk1975@yahoo.com

Hussain Musa Hussain

humhudhy02@gmail.com

Jan Laue

jan.laue@1tu.se

Anwer Hazim

anwer.hazim@koyauniversity.org

Sven Knutsson

Sven.Knutsson@1tu.se

Roland Pusch

drawrite.se@gmail.com

1 Department of Civil Environmental and Natural Resources Engineering, Lulea University of Technology, 97187 Lulea, Sweden

2 Department of Environment Engineering, college of Engineering, University of Babylon, Babylon, Iraq

3 Remote Sensing Center, University of Kufa, Kufa, Iraq

4 Koya University, Koya 46017, Iraq

\section{Introduction}

Selecting an adequate site for landfill is necessary to protect human and environment. To determine the proper site for disposal of solid waste optimally, the decision-makers need wide expertise to evaluate the lands within the study area that conforms to the requirements of environmental and scientific factors and the regulations and determinants of local and central governments. In addition, the selection site for a landfill should meet the following factors like rapid economic growth, social, population growth rate, improvements in living standards, growing environmental awareness, and government and municipality funding (Siddiqui et al. 1996; Lin and Kao 1999; Javaheri et al. 2006).

Different effective techniques were used for disposition of the municipal solid waste in terms of solid waste management. Examples of these techniques are landfills, recycling, biological treatment, and thermal treatment (Kontos et al. 2003; Moeinaddini et al. 2010). The landfill is considered the most common technique that is adopted in various countries because this process is a relatively cheap and simple method to be used. In developed countries, after recycling large parts of their waste, the remaining materials are still to be dumped in the proper location (Yesilnacar and Cetin 2008; Kim and Owens 2010).

The general outlines to be considered for the best design for the chosen landfill locations are: 
a) Managing the waste disposal in a sound way for short and long-terms by reducing negative impacts on environmental factors (water, soil, and air) and the risk to human health.

b) Inhibiting groundwater and surface water contamination by the leachate from landfill sites.

c) Eliminating the effects of burning waste on human and surrounding environment.

d) Controlling the gas emissions from landfill.

e) Reducing the negative impacts on the environment and human population (Ireland EPA 2000; Scott et al. 2005).

In Babylon Governorate, the existing landfill sites do not fulfill the international criteria like that adopted in developed countries. In 2013, the solid waste generated in this governorate was 483,221 tonnes and the solid waste generation rate was $0.67 \mathrm{~kg} / \mathrm{capita} /$ day. The budget spent on this process in that year was 15,894,716 USD (Chabuk et al. 2015). Groundwater depth in Babylon Governorate is shallow, which represent the main problem on human and environment when selecting the systematic sites for landfill. The water table depths in the whole area in the governorate vary from 0.423 to $15.97 \mathrm{~m}$ below the surface of the ground (Iraqi Ministry of Water Resources 2015). To solve the issue of selecting proper sites for landfill, the combination of the GIS software and multi-criteria decision-making (MCDM) methods can be used, which represent a quick way to achieve this purpose. The GIS software has an important role for the analysis of the input data and producing the required data for the landfill siting, since it has a high capability to deal with big different sizes of data (Kontos et al. 2003; Delgado et al. 2008; El Alfy et al. 2010; Şener et al. 2011). The GIS software and MCDM methods were applied to determine the best sites for landfills in each district in Babylon Governorate (Chabuk et al. 2016; Chabuk et al. 2017a, b, c, d, e).

Multi-criteria decision-making methods were used to derive the weights of criteria for the selected criteria. Then, these weights were applied on the maps of criteria in the GIS, after giving the suitable weights for the categories in each criterion map, to produce a suitable landfill site. Examples of such methods which were used in the current study are analytical hierarchy process (AHP) and ratio scale weighting (RSW).

Analytical hierarchy process (AHP) is a preferred method in multi-criteria decision-making methods. Thomas Saaty originally developed it in 1980. It is used to estimate the consistency weightings of criteria that resulted from constructing the matrix of pair-wise comparisons. In literatures, several studies used the analytical hierarchy process (AHP) method with GIS software in their studies to determine the weightings of criteria in the selecting sites for landfills (Siddiqui et al. 1996; Gemitzi et al. 2007; Ersoy and Bulut 2009; Eskandari et al. 2012; Kara and Doratli 2012; Alavi et al. 2013; Uyan 2014).

The ratio scale weighting (RSW) was used to obtain the weightings of criteria by allocating a proportion value for each criterion that is deserved through the decision-makers based on previous studies in this field and the opinion of experts.

In previous studies, several candidate landfill sites were identified in different areas using the ratio scale weighting (RSW) method and GIS (Halvadakis 1993; Sharifi and Retsios 2004; Sadek et al. 2006; Delgado et al. 2008; Nas et al. 2010). The change detection method was used in this study to compare the two output maps which were produced using the methods of AHP and RSW.

The purpose of this research is to obtain appropriate sites for landfill in Babylon Governorate, Iraq, using the ArcGIS 10.5 and the AHP and RSW methods (two methods of MCDM). In addition, the comparison method (change detection) was used to find the pixel percentage of matching and non-matching for the two raster maps of multi-criteria decision-making methods, and to verify the convenience of the chosen locations for the landfill on both output maps, AHP and RSW methods were used.

\section{Methodology}

\section{Study area}

In the central part of Iraq, Babylon Governorate is located approximately $100 \mathrm{~km}$ to the south of Baghdad (capital of Iraqi) (Al Khalidy et al., 2010) (Fig. 1). It is situated between latitude $32^{\circ} 5^{\prime} 41^{\prime \prime} \mathrm{N}$ and $33^{\circ} 7^{\prime} 36^{\prime \prime} \mathrm{N}$ and longitude $44^{\circ} 2^{\prime} 43^{\prime \prime}$ $\mathrm{E}$ and $45^{\circ} 12^{\prime} 11^{\prime \prime} \mathrm{E}$ (Fig. 1). Babylon Governorate has a rich history, and it contains several important archeological and religious sites, which includes one of the famous cities of the ancient world. The governorate has a population of about 2,200,000 up to the year 2017 and the inhabitants are distributed throughout its cities (Iraqi Ministry of Planning 2017). Babylon Governorate covers an area of $5337 \mathrm{~km}^{2}$. Administratively, Babylon Governorate is divided into five major cities (district) referred to as Qadhaa. These districts are AlHillah (capital of Babylon Governorate), Al-Hashimiyah, AlMusayiab, Al-Mahawil, and Al-Qasim. These districts include 16 smaller cities, which are called Nahiah.

\section{Landfill siting model}

The proposed model that will be led to obtaining the landfill sites in Babylon Governorate, Iraq, is summarized in Fig. 2.

\section{Site restrictions and buffer zones}

In the site selection process for a landfill, important areas are excluded by giving them the rating of zero (e.g., agricultural land, orchards, archeological sites, industrial areas, universities, treatment plant, and airport). On the other hand, buffer zones should be created around or on both sides of specific geographic features for each criterion in the GIS software. 


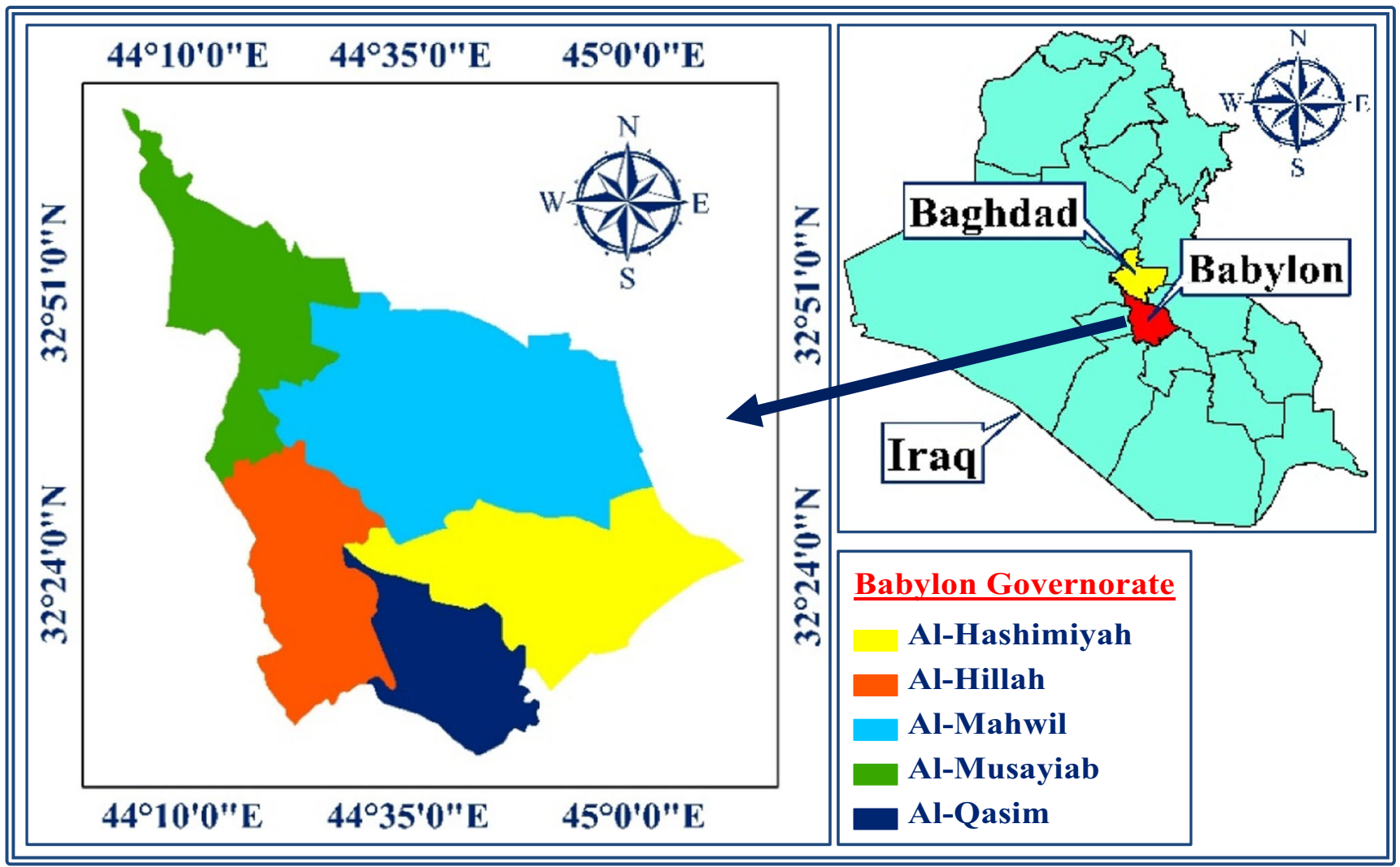

Fig. 1 Babylon Governorate, Iraq

Therefore, the site restrictions and buffer zones are necessary to protect the human health and to avoid any risk to the environment, as well as to fulfill the requirements of administrative regulations (Siddiqui et al. 1996; Ersoy and Bulut 2009). The buffer zones for urban centers, rivers, villages, roads, archeological sites, gas pipelines, oil pipelines, power lines and railways were created at distances of $5 \mathrm{~km}, 1 \mathrm{~km}, 1 \mathrm{~km}$, $0.5 \mathrm{~km}, 1 \mathrm{~km}, 300 \mathrm{~m}, 75 \mathrm{~m} 30 \mathrm{~m}$, and $0.5 \mathrm{~km}$, respectively.

\section{Layers of the criteria maps}

There are three sources used to prepare the required map layers in GIS software for the current study.

The first source was the vector data (shapefile feature classes) according to the internal reports of the Iraqi Ministry of Education (Iraqi Ministry of Education 2015). The first source was contributed to produce the separate shape file for urban areas, river, villages, elevation, slope, road, power lines, gas pipelines, oil pipeline, and railways.

In the second source, the relevant information in published maps was drawn as geometry features in separate polygons and storied their information and locations in shapefiles. The shapefile of "soil types" was obtained from the map of exploratory soil of Iraq (scale 1:1000, 000) (Buringh 1960). According to the World Digital Library (2013), the archeological map of Iraq (scale of 1:1500, 000) was used to identify the archeological and religious sites in Babylon Governorate. Then, the shape file of "archeological sites" was generated. The information on the published map (scale 1:1000,000) of "land capability map of Iraq" was converted to the shape file of "agricultural land use" according to the Iraqi Ministry of Water Resources (1990), and the categories of agricultural land use were verified by satellite images of Babylon Governorate. The published maps of industrial areas, treatment plants, and universities (scale 1:400,000) (Iraqi Ministry of Municipalities and Public Works 2009) were used to define the locations of industrial areas, treatment plants, and universities within Babylon Governorate.

The third source includes the implementation of the spatial interpolation method "kriging" within spatial analysis tools in ArcGIS between defined readings. The map of groundwater depths was produced using this process where data from 185 wells distributed in the governorate (Iraqi Ministry of Water Resources 2015) were used.

In this study, all vector maps were converted to the raster maps to perform the analysis process for landfill siting in GIS.

\section{Determination of the sub-criteria weights}

In this study, after analyzing the collected data for the 15 criteria, each criterion was classified into categories, and a value was given for each category as it deserves. This process 


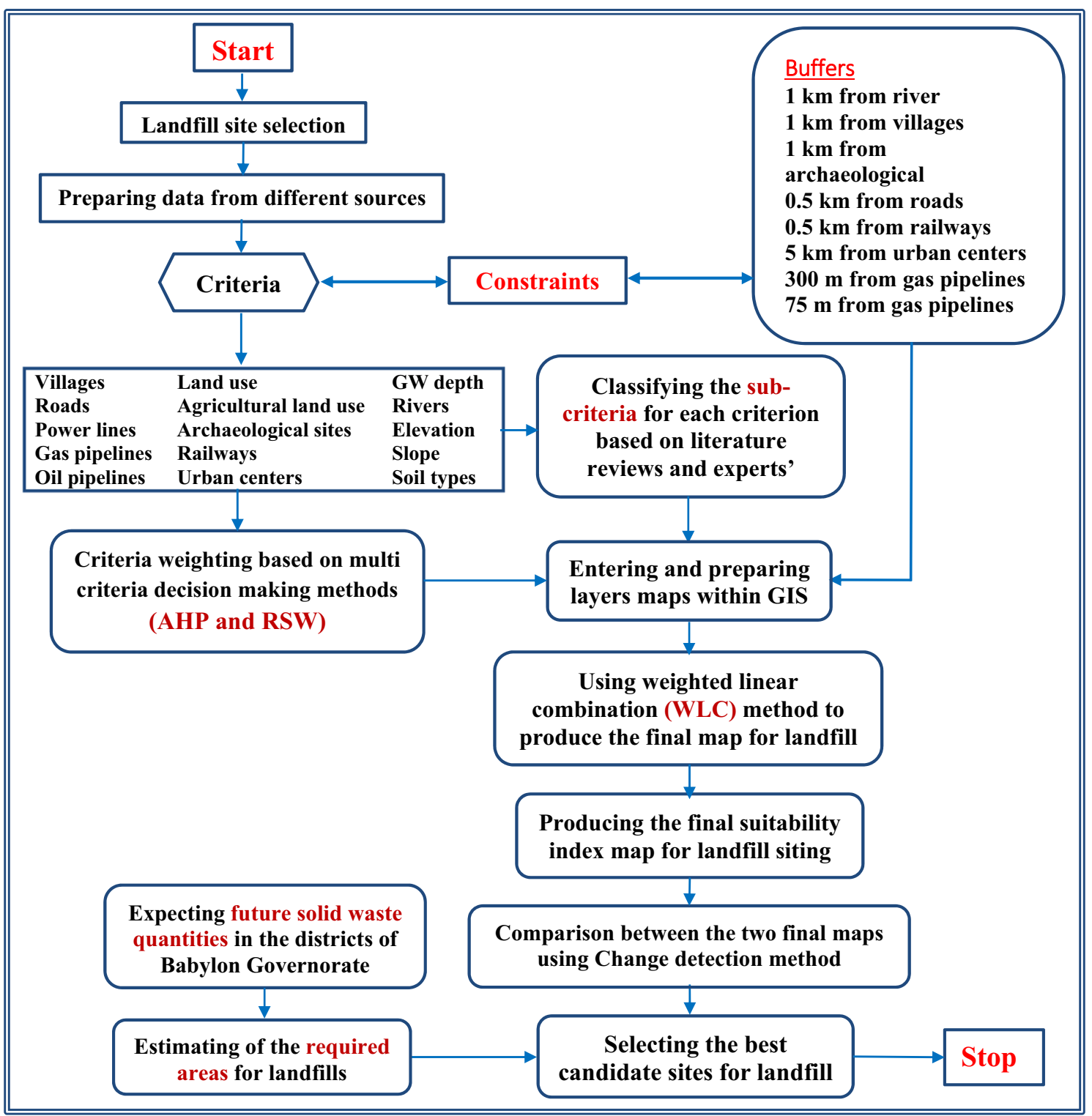

Fig. 2 The model for landfill siting in Babylon Governorate, Iraq

was done based on the experts' judgment, available data for the study area, and previous studies in this field. In this study, the geology criteria were ignored because there are no exposed rocks in this area, where alluvial deposits at depth of more than $50 \mathrm{~m}$ cover all the area of Babylon Governorate. Furthermore, Babylon Governorate is located outside the faults range (Jassim and Goff 2006). The 15 criterion and sub-criteria weights are presented briefly as follows:

\section{Groundwater depth}

The groundwater depth from the surface of the ground in most areas of Babylon Governorate is about $0.42-15.97 \mathrm{~m}$. The highest value of depth (deepest) was given the highest rating, while the lowest value of groundwater depth (shallowest) was given the lowest rating (Fig. 3a).
In literature, many researchers suggested various depths from the landfill ground surface to the groundwater table (Table 1).

\section{Urban centers}

In the current study, buffer zones of $\leq 5 \mathrm{~km}$ were assigned a rating of zero (Șener 2004; Effat and Hegazy 2012; Isalou et al. 2013). For buffer zones of $5-10 \mathrm{~km}$ and $10-15 \mathrm{~km}$, the ratings of 10 and 7, respectively, were given. Buffer zones > $15 \mathrm{~km}$ were assigned a grading of 4 (Fig. $3 \mathrm{~b}$ ).

The classification of urban centers' map was adopted to take into consideration the economic factors (transport and cost of land), as well as to protect the people and surrounding environment from negative impacts that results from the cumulative waste in landfills (e.g., diseases, insect, odors). 


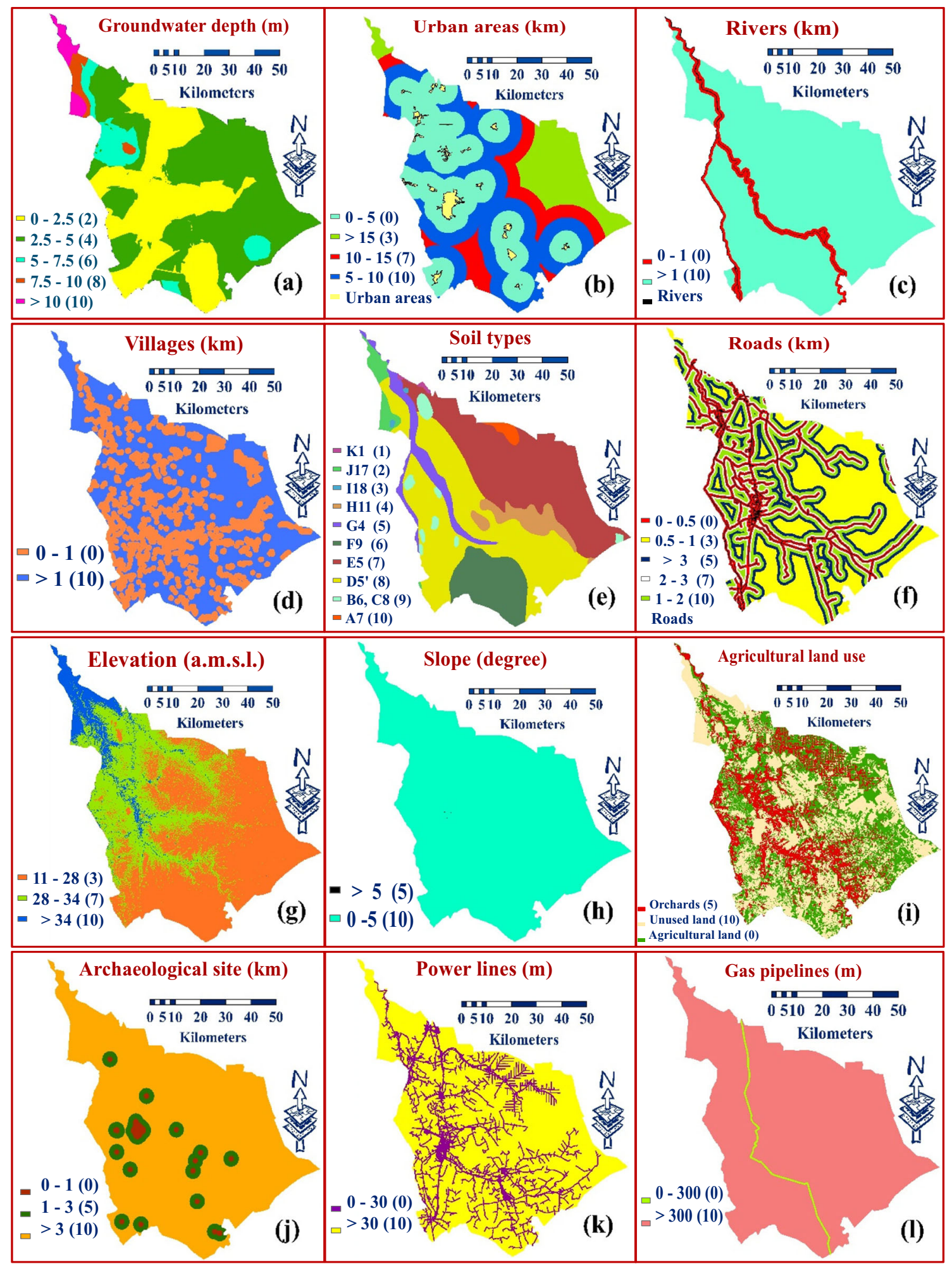

Fig. 3 Classified maps of Babylon Governorate for a ground water depth, $\mathbf{b}$ urban center, $\mathbf{c}$ rivers, $\mathbf{d}$ villages, e soil types, $\mathbf{f}$ roads, $\mathbf{g}$ elevation, $\mathbf{h}$ slope, $\mathbf{i}$ agricultural land use, $\mathbf{j}$ archeological site, $\mathbf{k}$ power lines, $\mathbf{l}$ gas pipelines

Moreover, the potential to expand the urban areas in the future was also considered. In addition, there is always an increase of social opposition to establishing landfills (Zeiss and Lefsrud 1995; Tagaris et al. 2003; Effat and Hegazy 2012).

\section{Rivers}

Shatt Al-Hillah River is considered the main source for water in Babylon Governorate, and it passes through most of the 
Table 1 The suggested depth of groundwater for the landfills according to previous studies

\begin{tabular}{lll}
\hline No. & Depth $(\mathrm{m})$ & References \\
\hline 1 & 1.5 & Alves et al. (2009) \\
2 & 6 & Effat and Hegazy (2012) \\
3 & 10 & Delgado et al. (2008) \\
4 & 15 & Ouma et al. (2011) \\
5 & 30 & Sadek et al. (2006) \\
6 & 2 & Current study \\
\hline
\end{tabular}

cities of the governorate. For protecting surface water from contamination within the study area, a landfill site is not allowed to be established within the buffer distance $\leq 1 \mathrm{~km}$ on both sides of a river (Sharifi et al. 2009; Eskandari et al. 2012; Kara and Doratli 2012; Yildirim 2012). Any distance lower than $1 \mathrm{~km}$, thus, was given a grading value of zero and any distance greater than $1 \mathrm{~km}$ was given a score value of 10 (Fig. 3c).

\section{Villages}

Due to the fact that there are high numbers of villages that are distributed throughout Babylon Governorate, buffer zones $\leq$ $1 \mathrm{~km}$ was allocated a score of zero (Charnpratheep et al. 1997; Șener 2004; Şener et al. 2006). Buffer zones $\geq 1 \mathrm{~km}$ were assigned a grading of 10 (Fig. $3 \mathrm{~d}$ ).

\section{Soil types}

There are eleventh types of soils in Babylon Governorate (Table 2 and Fig. 3e) (Buringh 1960). Alluvial deposits cover is about $50 \mathrm{~m}$ thick in Babylon Governorate (Jassim and Goff 2006).

\section{Roads}

The layer of "roads" in the Babylon Governorate consists of the main roads and highway. In the current study, the distance of 0.0 to $0.5 \mathrm{~km}$ on both sides of the roads is considered buffer zone, and it was given a score of zero (Șener et al. 2006; Șener et al. 2011; Effat and Hegazy 2012). Buffer distances of 1$2 \mathrm{~km}, 0.5-1 \mathrm{~km}, 2-3 \mathrm{~km}$, and $>3 \mathrm{~km}$ were given scores of 10 , 7,5 , and 3 , respectively (Fig. 3f).

Many factors should be taken into consideration for the roads' criterion such as the economic factors regarding transport; the distances from roads to a landfill site should be appropriate to avoid the negative esthetic impacts. In addition, to avoid spending additional money as possible as through constructing new roads connecting the main roads with the selected locations for landfill should be
Table 2 The soil types, symbol, and their rating weights in Babylon Governorate

\begin{tabular}{llll}
\hline No. & Soil type & Symbol & Rating \\
\hline A & Periodically flooded soils & A7 & 10 \\
B & Haur soils & B & 9 \\
C & Basin depression soils & C6 & 9 \\
D & River basin soils, poorly drained phase & E5' & 8 \\
E & River basin soils, silted phase & D5 & 7 \\
F & Silted haur and marsh soils & F9 & 6 \\
G & River levee soils & G4 & 5 \\
H & Active dune land & H11 & 4 \\
I & Sand dune land & I18 & 3 \\
J & Mixed gypsiferous desert land & J17 & 2 \\
K & Gypsiferous gravel soils & K1 & 1 \\
\hline
\end{tabular}

considered (Zeiss and Lefsrud 1995; Lin and Kao 1999; Moeinaddini et al. 2010; Nas et al. 2010).

\section{Elevation}

In this study, the digital elevation model (DEM) was used (Iraqi Ministry of Education 2015). In Babylon Governorate, the elevation is ranging between 11 and 72 above mean sea level (a.m.s.l.). The criterion of elevation was selected for this study to decrease the possibility of leachate percolation through the landfill layers and to prevent the risk of seasonal flooding runoff (Demesouka et al. 2014). The elevation map of Babylon Governorate was separated into three classes. In the current study, the elevations of 34-72 m (a.m.s.l.) were assigned a score value of 10 . Elevations between 28 and $34 \mathrm{~m}$ and 28 and 34 were and assigned values of 7 and 3, respectively (Fig. $3 \mathrm{~g}$ ).

\section{Slope}

The digital elevation model (DEM) of the study area was used to create the map of "slope." Most of the land in the governorate has a slope of less than $5^{\circ}$, and it was given a score of 10 (Fig. 3h). The range of land slope for the current study is suitable for landfill siting through decreasing runoff of pollutants from the landfill to the surrounding areas (Lin and Kao 1999).

\section{Agricultural land use}

The "agricultural land use" map in Babylon Governorate includes three categories (agricultural, orchards, and unused). The category of unused land was given the highest possible score of 10. The "orchards" and agricultural land were given a value of 5 and zero, respectively. This is to protect agricultural land from destruction and contamination (Fig. 3i). 


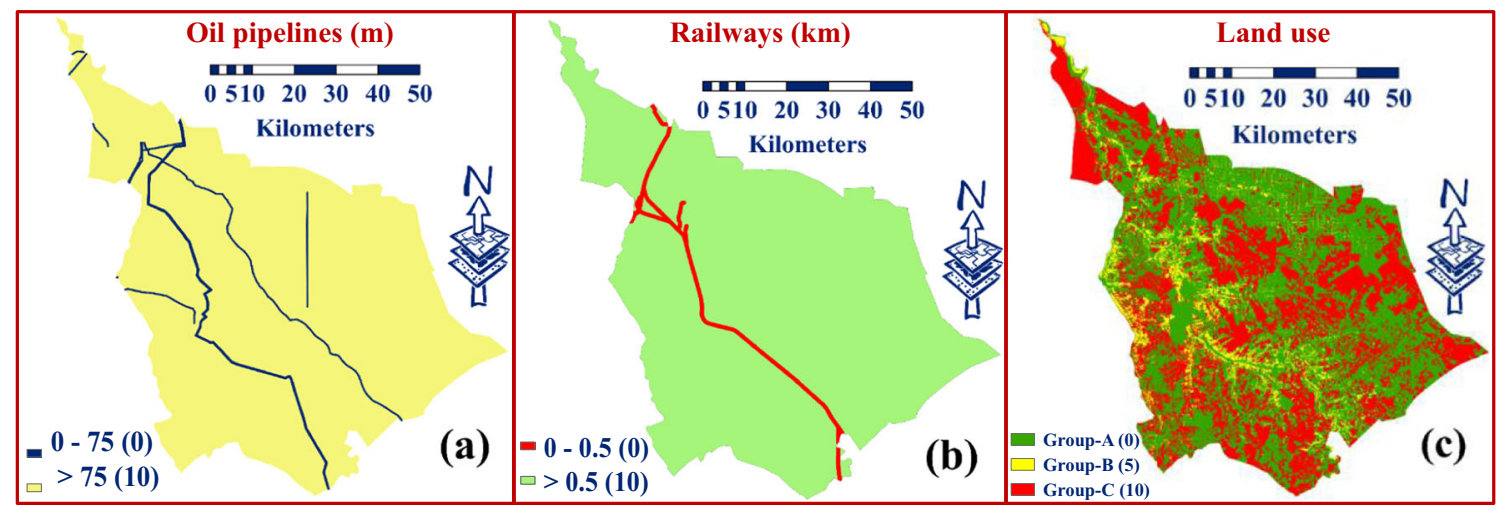

Fig. 4 Classified maps of Babylon Governorate for a oil pipelines, $\mathbf{b}$ railways, $\mathbf{c}$ land use

\section{Archeological sites}

In Babylon Governorate, there are many important archeological and religious sites. In this study, a value of zero was assigned for the buffer zones of $\leq 1 \mathrm{~km}$ from the archeological and religious sites in all directions (Gupta et al. 2003; Ersoy and Bulut 2009). A buffer zone more than $3 \mathrm{~km}$ around archeological and religious sites were assigned a value of 10 , while buffer zones of 1-3 $\mathrm{km}$ were assigned 5 (Fig. 3j).

\section{Power lines}

For the power lines, on both sides, a buffer distance $\leq 30 \mathrm{~m}$ was assigned a rating of zero to avoid risks associated with high-voltage (Şener 2004; Yildirim 2012). Buffer zones higher than $30 \mathrm{~m}$ were given a score value of 10 (Fig. 3k).

\section{Gas pipelines}

For the map of "gas pipelines," a grading value of zero was given for the buffer distance of less than $300 \mathrm{~m}$ from landfill sites to gas pipelines depending on the determinants of the Iraqi Ministry of Oil (2015). This distance was used to reduce the possible danger effect of fires that result from burning the waste on the pipelines of gas and oil. Buffer zone more than $300 \mathrm{~m}$ was given a score value of 10 (Fig. 31).

\section{Oil pipelines}

The buffer zones more than $75 \mathrm{~m}$ on both sides for oil pipelines was given a score of 10 based on the determinants of the Iraqi Ministry of Oil (2015) on both sides of oil pipelines. A rating of zero was assigned for the buffer zones less than $75 \mathrm{~m}$ (Fig. 4a).

\begin{tabular}{|c|c|c|c|c|c|c|c|c|c|c|c|c|c|c|c|c|}
\hline Criteria & 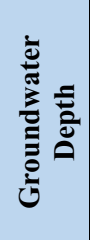 & 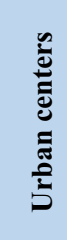 & 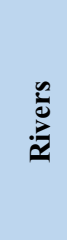 & 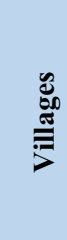 & 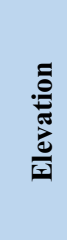 & 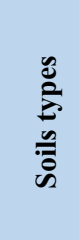 & $\frac{\check{0}}{\mathscr{\sigma}}$ & $\begin{array}{l}\tilde{\tilde{E}} \\
\tilde{\tilde{u}}\end{array}$ & 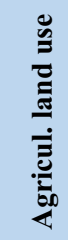 & 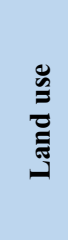 & 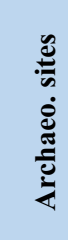 & 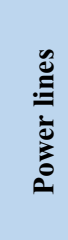 & 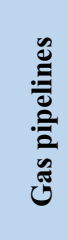 & $\frac{\mathscr{E}}{\frac{0}{0}}$ & $\sum_{\substack{\tilde{E}\\
}}^{\infty}$ & 竞 \\
\hline Groundwater Depth & 1 & 2 & 2 & 3 & 4 & 4 & 5 & 5 & 5 & 6 & 6 & 7 & 8 & 8 & 9 & 0.2004 \\
\hline Urban Centers & 0.50 & 1 & 1 & 2 & 3 & 3 & 4 & 4 & 4 & 5 & 5 & 6 & 7 & 7 & 8 & 0.1471 \\
\hline Rivers & 0.50 & 1 & 1 & 2 & 3 & 3 & 4 & 4 & 4 & 5 & 5 & 6 & 7 & 7 & 8 & 0.1471 \\
\hline Villages & 0.33 & 0.5 & 0.50 & 1 & 2 & 2 & 3 & 3 & 3 & 4 & 4 & 5 & 6 & 6 & 7 & 0.1038 \\
\hline Elevation & 0.25 & 0.33 & 0.33 & 0.50 & 1 & 1 & 2 & 2 & 2 & 3 & 3 & 4 & 5 & 5 & 6 & 0.0709 \\
\hline Soils types & 0.25 & 0.33 & 0.33 & 0.50 & 1 & 1 & 2 & 2 & 2 & 3 & 3 & 4 & 5 & 5 & 6 & 0.0709 \\
\hline Slope & 0.20 & 0.25 & 0.25 & 0.33 & 0.50 & 0.50 & 1 & 1 & 1 & 2 & 2 & 3 & 4 & 4 & 5 & 0.0463 \\
\hline Roads & 0.20 & 0.25 & 0.25 & 0.33 & 0.50 & 0.50 & 1 & 1 & 1 & 2 & 2 & 3 & 4 & 4 & 5 & 0.0463 \\
\hline Agricul. Land Use & 0.20 & 0.25 & 0.25 & 0.33 & 0.50 & 0.50 & 1 & 1 & 1 & 2 & 2 & 3 & 4 & 4 & 5 & 0.0463 \\
\hline Land use & 0.17 & 0.20 & 0.20 & 0.25 & 0.33 & 0.33 & 0.50 & 0.50 & 0.50 & 1 & 1 & 2 & 3 & 3 & 4 & 0.0302 \\
\hline Archaeological Sites & 0.17 & 0.20 & 0.20 & 0.25 & 0.33 & 0.33 & 0.50 & 0.50 & 0.50 & 1 & 1 & 2 & 3 & 3 & 4 & 0.0302 \\
\hline Power lines & 0.14 & 0.17 & 0.17 & 0.20 & 0.25 & 0.25 & 0.33 & 0.33 & 0.33 & 0.50 & 0.50 & 1 & 2 & 2 & 3 & 0.0207 \\
\hline Gas pipelines & 0.13 & 0.14 & 0.14 & 0.17 & 0.20 & 0.20 & 0.25 & 0.25 & 0.25 & 0.33 & 0.33 & 0.50 & 1 & 1 & 2 & 0.0146 \\
\hline Oil pipelines & 0.13 & 0.14 & 0.14 & 0.17 & 0.20 & 0.20 & 0.25 & 0.25 & 0.25 & 0.33 & 0.33 & 0.50 & 1 & 1 & 2 & 0.0146 \\
\hline Railways & 0.11 & 0.13 & 0.13 & 0.14 & 0.17 & 0.17 & 0.20 & 0.20 & 0.20 & 0.25 & 0.25 & 0.33 & 0.50 & 0.5 & 1 & 0.0107 \\
\hline
\end{tabular}

Fig. 5 Pair-wise comparisons' matrix for determining relative criteria weights for landfill siting 
Table 3 Random inconsistency indices for different values of $(n=1,2, \ldots, 15)$ (Saaty 1980)

\begin{tabular}{llllllllllllllll}
\hline$n$ & 1 & 2 & 3 & 4 & 5 & 6 & 7 & 8 & 9 & 10 & 11 & 12 & 13 & 14 & 15 \\
\hline RI & 0 & 0 & 0.58 & 0.9 & 1.12 & 1.24 & 1.32 & 1.41 & 1.45 & 1.49 & 1.51 & 1.48 & 1.56 & 1.57 & 1.59 \\
\hline
\end{tabular}

\section{Railway}

For the "railway" map, a rating of 10 was allocated to the buffer distances of $\geq 0.5 \mathrm{~km}$ on both sides of the railway. A value of zero was allocated for the buffer distance of $\leq 0.5 \mathrm{~km}$ (Wang et al. 2009; Nas et al. 2010; Demesouka et al. 2013) to avoid potential subsidence of land and visual intrusion (Baban and Flannagan 1998) (Fig. 4b).

\section{Land use}

To prepare the "land use" layer in Babylon Governorate, three groups were used. These groups are classified as A, B, and C. Group A includes archeological sites, rivers, universities, agricultural airport, treatment plant, industrial areas, agricultural land, urban centers, and villages. Group B contains plantation lands while group $\mathrm{C}$ comprises unoccupied lands. Figure $4 \mathrm{c}$ shows the ratings of 5 and 10 were allocated for groups $\mathrm{B}$ and $\mathrm{C}$, respectively, while a value of 0 was allocated to all categories within group $\mathrm{A}$.

\section{Multi-criteria decision-making methods}

Two methods of MCDM were implemented to determine the criteria weights in dissimilar procedure. These methods are analytical hierarchy process (AHP) and ratio scale weighting (RSW). These methods can be summarized as follows:

\section{Analytical hierarchy process method}

Saaty (1980) developed the analytic hierarchy process (AHP) method. It is based on theoretical foundation. This method was used to derive the important weightings for the chosen criteria in the governorate, using a comparison's matrix. The numerical scale of 9 points was used, where each point is used to express the relative importance between the two factors (Chabuk et al. 2017a).

In the AHP method, the matrix of pair-wise comparisons was created to derive the relative weights of criteria (Fig. 5). In the AHP method, the eigenvector (Egi) was calculated for each criterion. Then, the eigenvalue for each criterion was normalized to produce the relative weights or the priority vectors (Pri) through dividing each eigenvalue by their sum (Chabuk et al. 2017a).

To check the consistency between the resultant weights for criteria, the value of the consistency ratio (CR) was computed through using the following formula: (CR = CI / RI) (Saaty 1980). In the current study, the value of the consistency index for the 15 criteria were 0.43 , while the value of random index was 1.59 (see Table 3).
Table 4 The criterion weightings defined for the RSW method and normalized weights (Chabuk et al. 2017d)

\begin{tabular}{lllll}
\hline No. & Criteria & Ratio scale value & Standard weights $\left(\mathrm{SW}_{i}\right)$ & Relative weights $\left(\mathrm{RW}_{i}\right)$ \\
\hline 1 & Groundwater depth & 100 & 20 & 0.2012 \\
2 & Urban centers & 74 & 14.8 & 0.1489 \\
3 & Rivers & 73 & 14.6 & 0.1469 \\
4 & Villages & 52 & 10.4 & 0.1046 \\
5 & Elevation & 35 & 7 & 0.0704 \\
6 & Soils types & 35 & 7 & 0.0704 \\
7 & Slope & 23 & 4.6 & 0.0463 \\
8 & Roads & 23 & 4.6 & 0.0463 \\
9 & Agricultural land use & 23 & 4.6 & 0.0463 \\
10 & Land use & 15 & 3 & 0.0302 \\
11 & Archeological sites & 15 & 3 & 0.0302 \\
12 & Power lines & 10 & 2 & 0.0201 \\
13 & Gas pipelines & 7 & 1.4 & 0.0141 \\
14 & Oil pipelines & 7 & 1.4 & 0.0141 \\
15 & Railways & 5 & 1 & 0.0100 \\
& Sum & & 99.4 & 1 \\
\hline
\end{tabular}


Table 5 The relative weights of criteria calculated from the AHP and RSW methods

\begin{tabular}{|c|c|c|c|}
\hline \multirow[t]{2}{*}{ No. } & \multirow[t]{2}{*}{ Criteria } & \multicolumn{2}{|c|}{ Relative weights } \\
\hline & & AHP & RSW \\
\hline 1 & Groundwater depth & 0.2004 & 0.2012 \\
\hline 2 & Urban centers & 0.1471 & 0.1489 \\
\hline 3 & Rivers & 0.1471 & 0.1469 \\
\hline 4 & Villages & 0.1038 & 0.1046 \\
\hline 5 & Elevation & 0.0709 & 0.0704 \\
\hline 6 & Soils types & 0.0709 & 0.0704 \\
\hline 7 & Slope & 0.0463 & 0.0463 \\
\hline 8 & Roads & 0.0463 & 0.0463 \\
\hline 9 & Agricultural land use & 0.0463 & 0.0463 \\
\hline 10 & Land use & 0.0302 & 0.0302 \\
\hline 11 & Archeological sites & 0.0302 & 0.0302 \\
\hline 12 & Power lines & 0.0207 & 0.0201 \\
\hline 13 & Gas pipelines & 0.0146 & 0.0141 \\
\hline 14 & Oil pipelines & 0.0146 & 0.0141 \\
\hline \multirow[t]{2}{*}{15} & Railways & 0.0107 & 0.0100 \\
\hline & Sum & 1 & 1 \\
\hline
\end{tabular}

The consistency is acceptable when the value of the consistency ratio is less than 0.1 . Therefore, the $C R$ value was 0.027 and smaller than 0.1 .

\section{Ratio scale weighting method}

The second method which was applied in this study was the ratio scale weighting (RSW) method. In this method, the weights of criteria are given directly by decision-makers based on previous studies in this field. In this method, the decisionmakers are giving a convenient proportional value for each criterion. A value of 100 is assigned to the most important criteria to be the base value for the other criteria. Each criterion is given the proportionally value smaller than 100 according to its importance relative to other criteria. The criteria are arranged proportionally from the most to the lowest significant (Șener 2004). Table 4 shows the weights of criteria for landfill siting using the RSW method.
To calculate the standard weights (SWi) in the ratio scale weighting (RSW) method, the proportional weight value for each criterion was divided by the value of proportional weight for the lowest importance criterion. The standard weights represent the new weights for each criterion.

The standard weights of criteria were converted to relative weights through divided each criterion standard weight by their summation, using Eq. (1) as follows (Chabuk et al. 2017d).

$\mathrm{RW}_{i}=\frac{\mathrm{SW}_{i}}{\sum_{j=1}^{n} \mathrm{SW}_{j}} j=1,2, n$

where $\mathrm{RW}_{i}$ is the relative weight for each criterion; $\mathrm{SW}_{i}$ is the standard weights of each criterion of area $i$ under criterion $j ; n$ is the criteria number.

\section{Results and discussion}

\section{Final landfill siting maps}

In order to implement the analysis process for producing the final map of landfills in GIS, all vector maps were converted to the raster maps. After producing the weightings for the 15 raster maps of criteria from AHP and RSW methods (Table 5), and the weights of categories for criteria, the special analysis tool "Map Algebra" in GIS software was applied to create the final raster maps of the suitability index for landfills, using Eq. (2) as follows.

$M_{i}=\sum_{k=1}^{n} \mathrm{CW}_{k} \times \mathrm{SC}_{i k}$

where $M_{i}$ is the index of suitability for area $i ; n$ is the number of criteria; $\mathrm{CW}_{k}$ is the relative weighting of each criterion; $\mathrm{SC}_{i k}$ is the rating value of area $i$ under criterion $k$.

Table 6 shows the summary of the number of pixels and the areas with their proportion for the maps' categories for landfill siting, using AHP and RSW methods. Figure 6 represents the final raster maps of the suitability index of the selection sites for landfill using AHP and RSW.
Table 6 The pixels and the areas with their proportion for the categories in each map for landfill siting, using AHP and RSW

\begin{tabular}{llllllll}
\hline \multirow{2}{*}{ Category } & \multicolumn{2}{l}{ AHP method } & & & \multicolumn{2}{l}{ RSW method } \\
\cline { 2 - 3 } & No. pixels & Area $\left(\mathrm{km}^{2}\right)$ & Proportion $\%$ & & No. pixels & Area $\left(\mathrm{km}^{2}\right)$ & Proportion \% \\
\hline USA & 368,963 & 230.51 & 4.34 & & 333,854 & 208.58 & 3.92 \\
MDSA & $1,397,117$ & 873.50 & 16.42 & & $1,237,999$ & 773.59 & 14.54 \\
SA & $4,834,989$ & 3022.67 & 56.82 & & $5,251,135$ & 3283.18 & 61.73 \\
MSA & $1,910,033$ & 1192.62 & 22.42 & & $1,688,114$ & 1053.95 & 19.81 \\
\hline
\end{tabular}




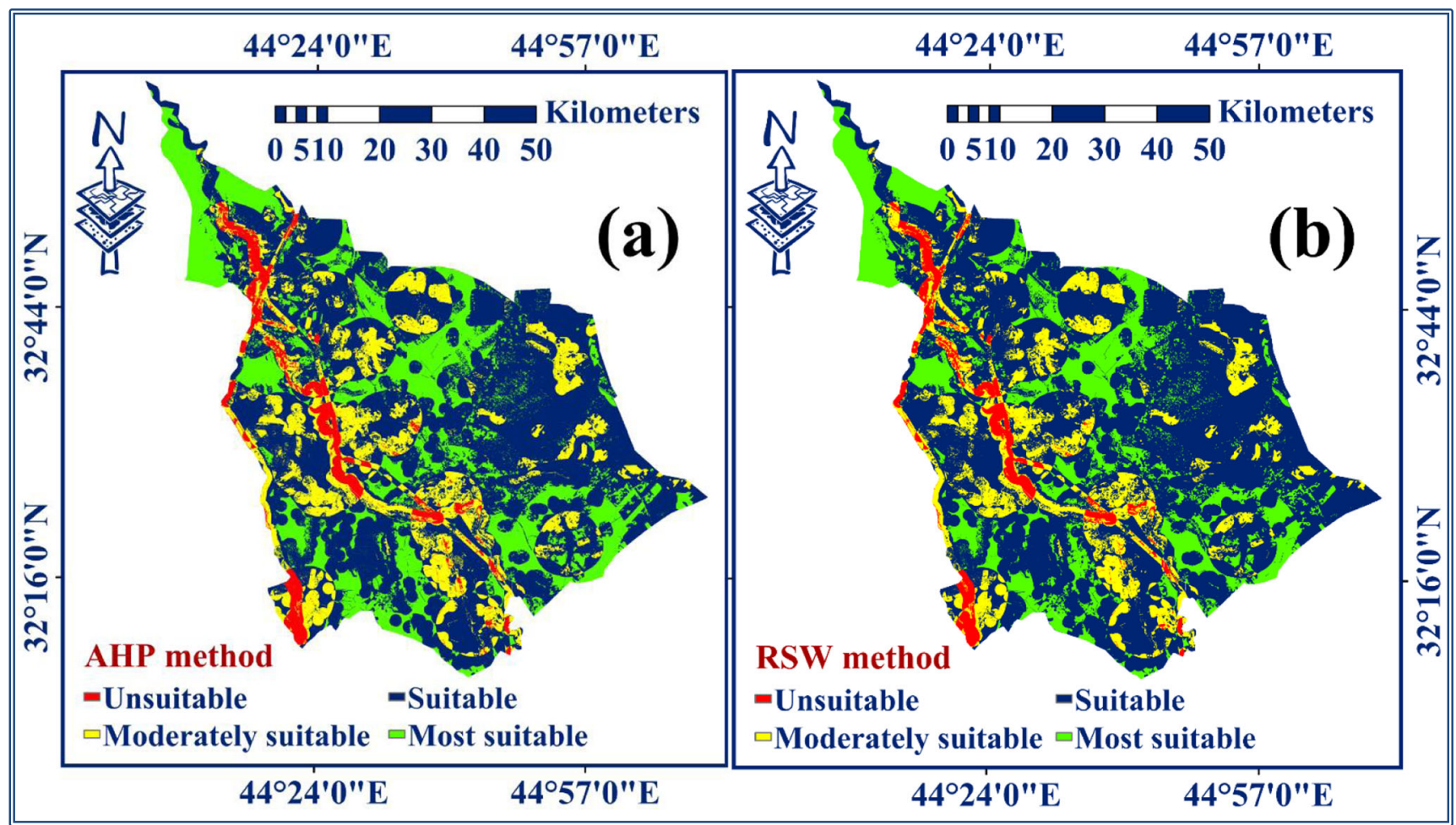

Fig. 6 The maps of landfill siting in Babylon governorate using methods of a AHP and $\mathbf{b}$ RSW

\section{Change detection method}

According to Jin et al. (2013), the U.S. National Land Cover Database (NLCD) introduced the method of change detection. According to Chabuk et al. (2017d), the change detection method was applied for comparing the pixels of categories for the final raster maps in Babylon Governorate. In this study, each raster map was classified into four categories. The purpose of this method is to calculate the matching pixels for all categories and the non-matching pixels for every two similar categories for all categories.

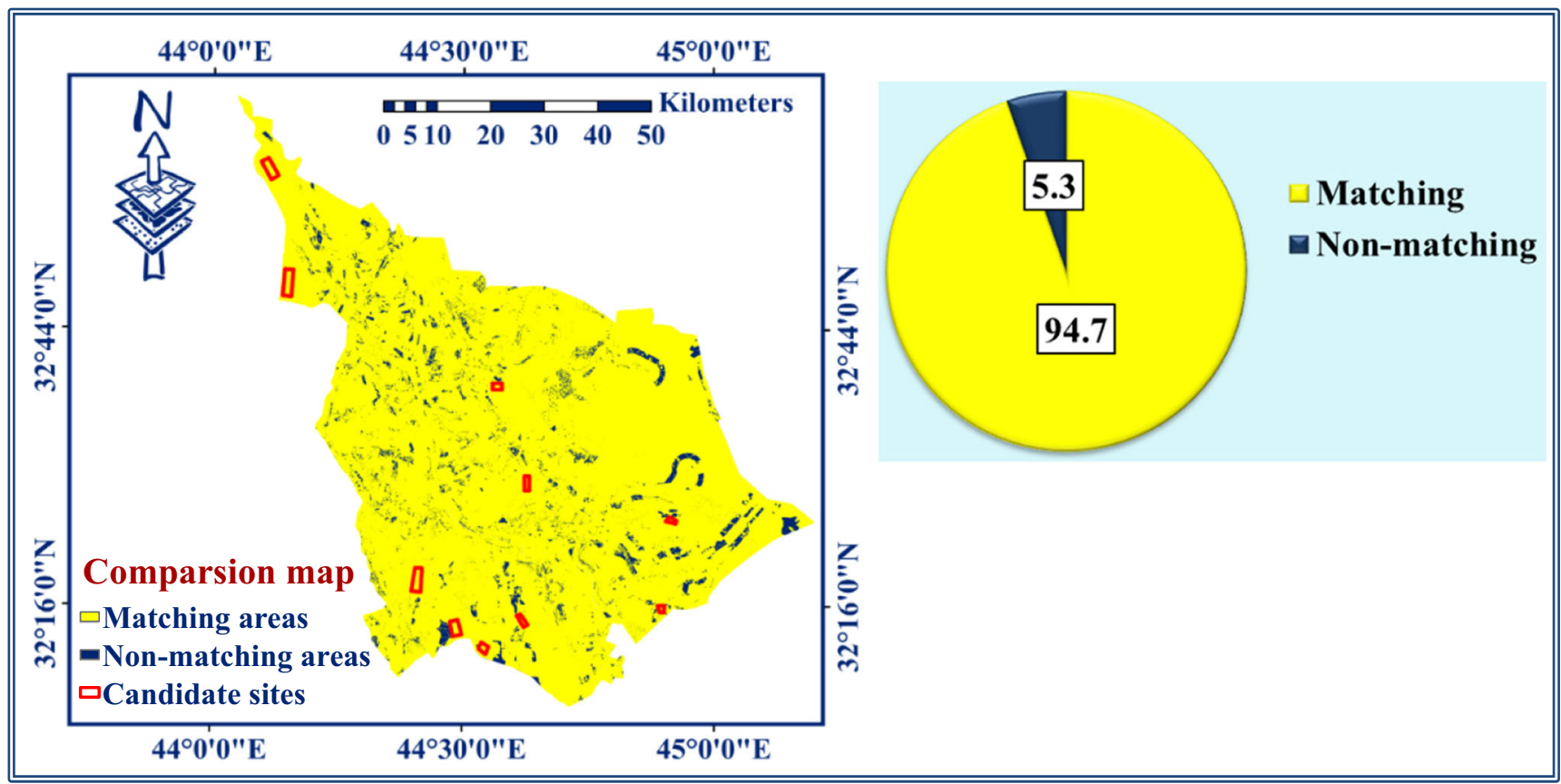

Fig. 7 The comparison map for the AHP and RSW methods using change detection method 
Table 7 The data of comparison map that generated from combining of the methods of AHP and RSW

\begin{tabular}{llllll}
\hline Value & Count & Categories (AHP) & Categories (SRS) & Pixel ratios & Classification \\
\hline 1 & $8,059,847$ & All similar categories & All similar categories & 94.70 & Matching \\
2 & 35,109 & (USA) 4 & (USA) 4 & 0.41 & Non-matching \\
4 & 194,227 & (MDSA) 3 & (MDSA) 3 & 2.28 & Non-matching \\
5 & 221,919 & (MSA) 1 & (MSA) 1 & 2.61 & Non-matching \\
\hline
\end{tabular}

USA unsuitable areas, MDSA moderately suitable areas, MSA most suitable areas
In this context, four categories exist. These are (i) most suitable areas (MSA), (ii) suitable areas (SA), (iii) moderately suitable areas (MDSA), and (iv) unsuitable areas (USA) (Chabuk et al. 2017d). In the GIS, the spatial analysis tool "Map Algebra" was applied using the formula "(AHP raster map) Diff (RSW raster map)" for comparison between the two maps using the change detection method. The process of comparison was applied to verify the appropriateness of the selected sites for landfill on the two resulted maps. The map of comparison resulted from combining the two final maps of AHP and RSW methods in Babylon Governorate (Fig. 7).

Table 7 shows the results obtained from the comparison map using the change detection method. It was noticed that there are two main categories, which are matching and nonmatching areas for each two similar categories. In the comparison map (Fig. 7), the matching pixels' ratio was $94.7 \%$ (in yellow), while the non-matching pixels' ratio was 5.3\% (blue). All selected sites for landfills are located within the category of matching areas on the comparison map.

\section{Selecting candidate sites for landfill}

To calculate the quantity of waste produced for the year 2030 in Babylon Governorate and its districts, Eq. (3) was used for this purpose according to Chabuk et al. (2015).

$$
\begin{aligned}
& \operatorname{SWQ}_{(r t)(\text { for specific year })} \\
& =\left(\left(P_{0(2013)}(1+0.0299)^{n}\right) \times\left(\operatorname{GRW}_{(2013)}(1+0.01)^{n}\right) \times(365 / 1000)\right)
\end{aligned}
$$

This equation was constructed based on three factors. These are:

(i) The annual increment rate of (1\%) for waste generation rate (WGR) starting from the year 2013.

(ii) Solid waste generation rate for Babylon Governorate in 2013 (SWGR).

Table 8 The summary of computing the solid waste quantity in 2030, and the solid waste cumulative quantities for the years 2020-2030 (Chabuk et al. 2015)

\begin{tabular}{lllllll}
\hline District & $\begin{array}{l}\text { Population, } \\
P_{o(2013)}\end{array}$ & $\begin{array}{l}\text { Population, } \\
P_{t(2030)}\end{array}$ & $\begin{array}{l}\text { Solid waste quantity } \\
\text { SWQ (2013) (T) }\end{array}$ & $\begin{array}{l}\text { SWGR (kg/ } \\
\text { capita day) (2013) }\end{array}$ & $\begin{array}{l}\text { Solid waste quantity } \\
\text { SWQ (2030) (T) }\end{array}$ & $\begin{array}{l}\text { Solid waste cumulative quantity } \\
\text { SWCQ (2020-2030) (T) }\end{array}$ \\
\hline Al-Hillah & 807,777 & $1,332,930$ & 238,244 & 0.82 & 472,474 & $4,300,864$ \\
Al-Qasim & 184,605 & 304,621 & 38,913 & 0.57 & 76,374 & 695,219 \\
Al-Mahawil & 336,148 & 554,685 & 49,377 & 0.4 & 96,389 & 877,419 \\
Al-Hashimiyah & 270,020 & 445,566 & 51,491 & 0.52 & 100,155 & 911,695 \\
Al-Musayiab & 374,684 & 618,274 & 105,196 & 0.77 & 205,792 & $1,873,295$ \\
\begin{tabular}{l} 
Babylon \\
\multicolumn{1}{l}{ Governorate }
\end{tabular} & $1,973,234$ & $3,556,966$ & 483,221 & 0.67 & $1,030,174$ & $8,752,506$ \\
\hline
\end{tabular}

Table 9 The volume of waste in 2030 and its cumulative volume for the years 2020-2030 in Babylon Governorate and its districts

\begin{tabular}{lll}
\hline District & Waste volume in $2030\left(\mathrm{~m}^{3}\right)$ & Cumulative waste volume 2020-2030 $\left(\mathrm{m}^{3}\right)$ \\
\hline Al-Hillah & 674,963 & $6,144,091$ \\
Al-Qasim & 109,106 & 993,170 \\
Al-Mahawil & 137,699 & $1,253,456$ \\
Al-Hashimiyah & 143,079 & $1,302,421$ \\
Al-Musayiab & 293,989 & $2,676,136$ \\
Babylon Governorate & $1,471,677$ & $12,503,580$ \\
\hline
\end{tabular}


Table 10 The required areas, selected sites' areas, and its locations for landfills in the Babylon Governorate districts of (Chabuk et al. 2017b)

\begin{tabular}{|c|c|c|c|c|}
\hline \multirow[t]{2}{*}{ District } & \multirow[t]{2}{*}{ Required area $\left(\mathrm{km}^{2}\right)$} & \multicolumn{2}{|c|}{ Area of candidate sites } & \multirow[t]{2}{*}{ Location } \\
\hline & & Site & Area $\left(\mathrm{km}^{2}\right)$ & \\
\hline \multirow[t]{4}{*}{ Al-Hillah } & \multirow[t]{4}{*}{3.4} & Hi-1 & 6.768 & Latitude $32^{\circ} 15^{\prime} 46^{\prime \prime} \mathrm{N}$ \\
\hline & & & & Longitude $44^{\circ} 28^{\prime} 55^{\prime \prime} \mathrm{E}$ \\
\hline & & $\mathrm{Hi}-2$ & 8.204 & Latitude $32^{\circ} 13^{\prime} 43^{\prime \prime} \mathrm{N}$ \\
\hline & & & & Longitude $44^{\circ} 29^{\prime} 15^{\prime \prime} \mathrm{E}$ \\
\hline \multirow[t]{4}{*}{ Al-Qasim } & \multirow[t]{4}{*}{0.55} & Q-1 & 2.766 & Latitude $32^{\circ} 11^{\prime} 43^{\prime \prime} \mathrm{N}$ \\
\hline & & & & Longitude $44^{\circ} 32^{\prime} 26^{\prime \prime} \mathrm{E}$ \\
\hline & & Q-2 & 2.055 & Latitude $32^{\circ} 14^{\prime} 38^{\prime \prime} \mathrm{N}$ \\
\hline & & & & Longitude $44^{\circ} 37^{\prime} 10^{\prime \prime} \mathrm{E}$ \\
\hline \multirow[t]{4}{*}{ Al-Hashimiyah } & \multirow[t]{4}{*}{0.72} & Hs-1 & 1.288 & Latitude $32^{\circ} 15^{\prime} 54^{\prime \prime} \mathrm{N}$ \\
\hline & & & & Longitude $44^{\circ} 53^{\prime} 38^{\prime \prime} \mathrm{E}$ \\
\hline & & Hs-2 & 1.374 & Latitude $32^{\circ} 24^{\prime} 51^{\prime \prime} \mathrm{N}$ \\
\hline & & & & Longitude $44^{\circ} 54^{\prime} 41^{\prime \prime} \mathrm{E}$ \\
\hline \multirow[t]{4}{*}{ Al-Mahawil } & \multirow[t]{4}{*}{0.70} & Ma-1 & 2.950 & Latitude $32^{\circ} 29^{\prime} 59^{\prime \prime} \mathrm{N}$ \\
\hline & & & & Longitude $44^{\circ} 41^{\prime} 2^{\prime \prime} \mathrm{E}$ \\
\hline & & Ma-2 & 2.218 & Latitude $32^{\circ} 38^{\prime} 12^{\prime \prime} \mathrm{N}$ \\
\hline & & & & Longitude $44^{\circ} 34^{\prime} 9^{\prime \prime} \mathrm{E}$ \\
\hline \multirow[t]{4}{*}{ Al-Musayiab } & \multirow[t]{4}{*}{1.4} & $\mathrm{Mu}-1$ & 7.965 & Latitude $32^{\circ} 48^{\prime} 39^{\prime \prime} \mathrm{N}$ \\
\hline & & & & Longitude $44^{\circ} 8^{\prime} 59^{\prime \prime} \mathrm{E}$ \\
\hline & & $\mathrm{Mu}-2$ & 5.952 & Latitude $33^{\circ} 0^{\prime} 14^{\prime \prime} \mathrm{N}$ \\
\hline & & & & Longitude $44^{\circ} 6^{\prime} 46^{\prime \prime} \mathrm{E}$ \\
\hline
\end{tabular}

(iii) The expected population for the year (2030) was built based on the existed population in 2013 and using the annual growth rate of 2.99\% (Iraqi Ministry of Planning 2013).

The solid waste cumulative quantity during the years from 2020 to 2030 in Babylon Governorate and its districts was estimated using Eq. (3) (Table 8). The solid waste cumulative quantity that generated by 2030 can be computed, using Eq. (4) as follows:

$\operatorname{SWCQ}_{(r)}=\mathrm{SWQ}_{(r t)}+\mathrm{SWCQ}_{(r t-1)}$

where $\mathrm{SWCQ}_{(r)}$ is the solid waste cumulative quantity for the particular year (tonne); $\mathrm{SWQ}_{(r t)}$ is the solid waste quantity for the particular year (tonne); $\mathrm{SWCQ}_{(r t-1)}$ is the solid waste cumulative quantity for the previous year before the particular year (tonne).

The volume of waste in the year 2030 and the cumulative waste volume from 2020 to 2030 in the governorate and its districts are shown in Table 9. These values were calculated based on the following information:

The data are given in Table 8 .

Values of waste volume in 2030 are the result of dividing the solid waste quantity in 2030 and solid waste cumulative quantity for the years $2020-2030$ by the density of waste $\left(700 \mathrm{~kg} \mathrm{~m}^{-3}\right)$ (Oweis and Khera 1998; Worrell and Vesilind 2002; UNEPIETC 2006).
The required area of candidate sites for landfills was calculated through dividing the expected cumulative volume of solid waste generated from 2020 to 2030 in each district by the $2 \mathrm{~m}$ height of solid waste that will be placed on the top surface of the candidate sites. Then, the result of the required area in each district was multiplied by $10 \%$ to provide a factor of safety when selecting the candidate sites (Chabuk et al. 2015). The initial reasons of selecting the height of solid waste in these sites as $2 \mathrm{~m}$ are as follows:

- The groundwater depth in the study areas is shallow.

- To reduce the cost of constructing a perimeter berm around the sites.

- To reduce soil subsidence or settlement under the load of cumulative waste that will be placed over the surface at the selected sites.

In each district, two candidate sites were selected for landfill among many sites that were located within the category of the "most suitable." The required areas and the selected sites' areas for landfills in each district are tabulated in Table 10.

For accuracy purposes, the selected sites were checked on the satellite images of the governorate to verify their suitability within the districts of Babylon Governorate (Fig. 8). 


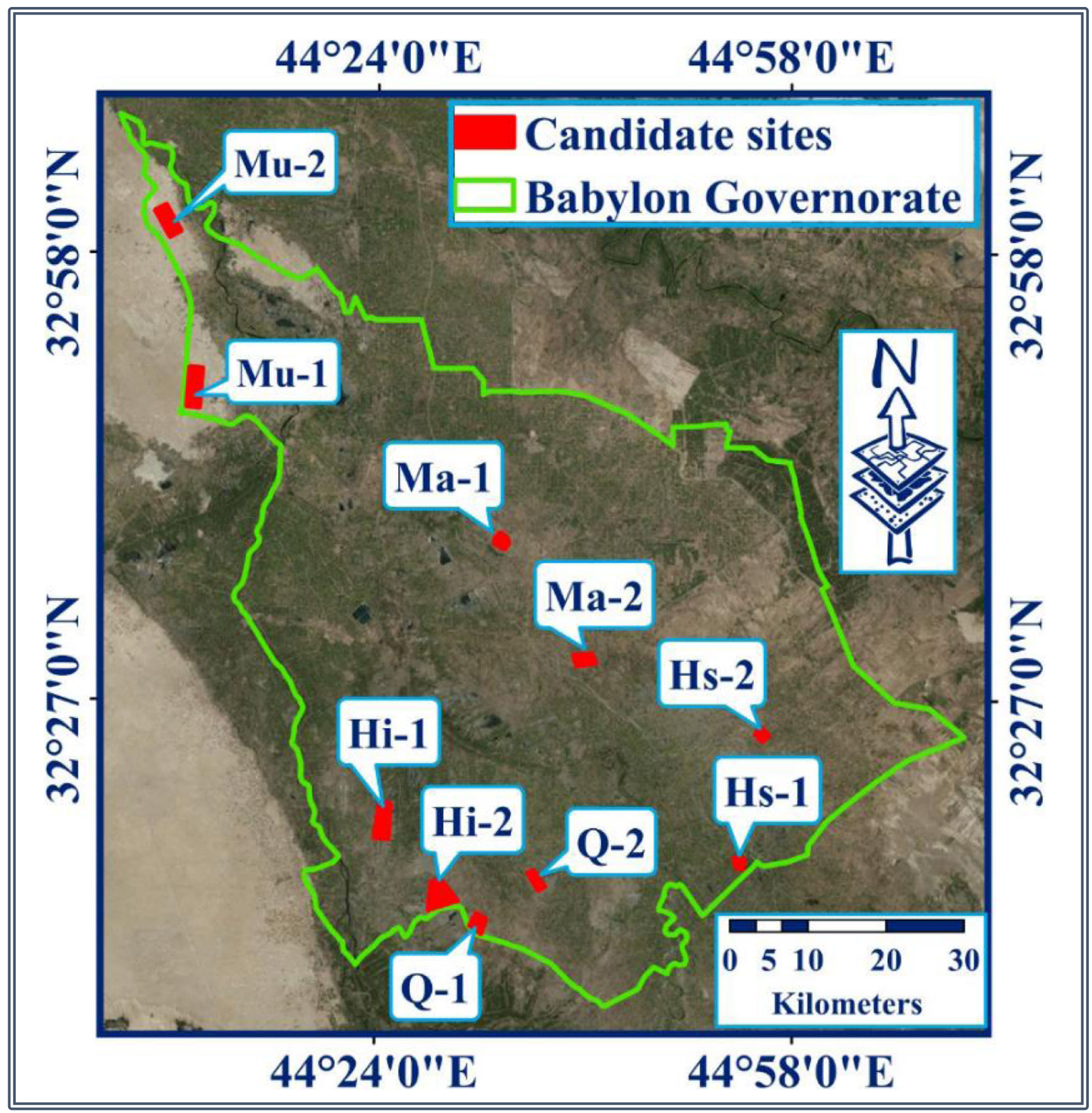

Fig. 8 Candidate sites for landfill on the satellite images of the Babylon Governorate

\section{Conclusions}

The present waste disposal sites in Babylon Governorate do not conform to the environmental and scientific criteria, and it influences human health. The purpose of the current study is to select the most suitable landfill sites in the governorate using the GIS software (10.5) and methods of AHP and RSW. Thus, 15 maps of criteria were entered into the GIS to produce the final map for landfill siting. The 15 layers are groundwater depth, urban centers, rivers, villages, soil types, elevation, agriculture lands use, roads, slope, land use, archeological sites, gas pipelines, oil pipelines, power lines, and railways.

Two MCDM methods were implemented in different styles to find the relative weights for each criterion. The analytic hierarchy process (AHP) was the first method, where a matrix of pair-wise comparisons between each criterion to derive the weight to each criterion was used. The second method was the 
ratio scale weighting (RSW). This method is based on the experts' opinion and previous studies in this field by giving proportion values for each criterion according to its importance among other criteria. Then, the special analysis tool in GIS "Map Algebra" was used to generate the final map to select the candidate sites for landfill for each method.

The two final maps that resulted from the two methods of MCDM (AHP and RSW) were combined in the GIS. Then, the change detection method was used to find the matching and non-matching areas on the final raster maps of AHP and RSW methods. The comparison process of the change detection method was applied to check the appropriateness of the landfill sites that were selected in Babylon Governorate on the two maps that were produced from the AHP and RSW methods.

Finally, ten candidate sites were obtained on the final maps for landfill in Babylon Governorate among several sites (two for each district). All the selected sites were located within the category of "most suitable" on the final maps of MCDM methods and within the matching areas in the comparison map. It was found that these sites are suitable to accommodate the cumulative solid waste for the years 2020-2030. This procedure will allow the planners and decision-makers to apply it in other areas in Iraq that have similar conditions (especially in the arid areas) when selecting a new landfill site.

Open Access This article is distributed under the terms of the Creative Commons Attribution 4.0 International License (http:// creativecommons.org/licenses/by/4.0/), which permits unrestricted use, distribution, and reproduction in any medium, provided you give appropriate credit to the original author(s) and the source, provide a link to the Creative Commons license, and indicate if changes were made.

\section{References}

Al Khalidy KS, Chabuk AJ, Kadhim MM (2010) Measurement of lead pollution in the air of Babylon Governorate, Iraq during year 2010. World Acad Sci Eng Technol 6:830-833

Alavi N, Goudarzi G, Babaei AA, Jaafarzadeh N, Hosseinzadeh M (2013) Municipal solid waste landfill site selection with geographic information systems and analytical hierarchy process: a case study in Mahshahr County, Iran. Waste Manag Res 3:98-105

Alves M, Lima B, Evsukoff AG, Vieira IN (2009) Developing a fuzzy decision support system to determine the location of a landfill site. Waste Manag Res 27:641-651

Baban SM, Flannagan J (1998) Developing and implementing GIS assisted constraints criteria for planning landfill sites in the UK. Plan Pract Res 13:139-151

Buringh P (1960) Soils and soil conditions in Iraq. the Ministry of Agriculture, Baghdad

Chabuk A, Al-Ansari N, Hussain HM, Knutsson S, Pusch R (2015) Present status of solid waste management at Babylon Governorate, Iraq. Engineering 7:408-423

Chabuk A, Al-Ansari N, Hussain HM, Knutsson S, Pusch R (2016) Landfill site selection using Geographic Information System (GIS) and AHP: a case study Al-Hillah Qadhaa, Babylon, Iraq. Waste Manag Res 34(5):427-437

Chabuk A, Al-Ansari N, Hussain HM, Knutsson S, Pusch R (2017a) Combining GIS applications and method of multi-criteria decision-making (AHP) for landfill siting in Al-Hashimiyah Qadhaa, Babylon, Iraq. Sustainability 9:123-141

Chabuk A, Al-Ansari N, Hussain HM, Knutsson S, Pusch R, Laue J (2017b) Landfills site selection in Babylon, Iraq. J Earth Sci Geotech Eng 7(4):1-15

Chabuk A, Al-Ansari N, Hussain MH, Kamaleddin S, Knutsson S, Pusch R (2017c) GIS-based assessment of combined AHP and SAW methods for selecting suitable sites for landfill in Al-Musayiab Qadhaa, Babylon, Iraq. Environ Earth Sci 76:209-220

Chabuk A, Al-Ansari N, Hussain MH, Knutsson S, Pusch R, Laue J (2017d) Landfill sitting by two methods in Al-Qasim, Babylon, Iraq and comparing them using change detection method. Engineering 9:723-737

Chabuk A, Al-Ansari N, Hussain MH, Knutsson S, Pusch R (2017e) Landfill sites selection using analytical hierarchy process and ratio scale weighting: case study of Al-Mahawil, Babylon, Iraq. Engineering 9:123-141

Charnpratheep K, Zhou Q, Garner B (1997) Preliminary landfill site screening using fuzzy geographical information systems. Waste Manag Res 15:197-215

Delgado OB, Mendoza M, Granados EL, Geneletti D (2008) Analysis of land suitability for the siting of inter-municipal landfills in the Cuitzeo Lake Basin, Mexico. Waste Manag 28:1137-1146

Demesouka OE, Vavatsikos A, Anagnostopoulos K (2013) Suitability analysis for siting MSW landfills and its multicriteria spatial decision support system: method, implementation and case study. Waste Manag 33:1190-1206

Demesouka OE, Vavatsikos AP, Anagnostopoulos KP (2014) GIS-based multicriteria municipal solid waste landfill suitability analysis: a review of the methodologies performed and criteria implemented. Waste Manag Res 32:270-296

Effat HA, Hegazy MN (2012) Mapping potential landfill sites for North Sinai cities using spatial multicriteria evaluation. Egypt J Remote Sens Space Sci 15:125-133

El Alfy Z, Elhadary R, Elashry A (2010) Integrating GIS and MCDM to Deal with landfill site selection. Int J Eng Technol 10:32-42

Ersoy H, Bulut F (2009) Spatial and multi-criteria decision analysis-based methodology for landfill site selection in growing urban regions. Waste Manag Res 27:489-500

Eskandari M, Homaee M, Mahmodi S (2012) An integrated multi criteria approach for landfill siting in a conflicting environmental, economical and socio-cultural area. Waste Manag 32:1528-1538

Gemitzi A, Tsihrintzis VA, Voudrias E, Petalas C, Stravodimos G (2007) Combining geographic information system, multicriteria evaluation techniques and fuzzy logic in siting MSW landfills. Environ Geol 51:797-811

Gupta R, Kewalramani MA, Ralegaonkar RV (2003) Environmental impact analysis using fuzzy relation for landfill siting. J Urban Plann Dev 129:121-139

Halvadakis CP (1993) Municipal solid waste landfill siting in Greece the case of the greater Hania region, Crete. Ekistics 60:358-359 4552

Iraqi Ministry of Education (2015) Data of the directorate general, internal reports. The Department of Scientific Affairs, Baghdad

Iraqi Ministry of Municipalities and Public Works (2009) Structural plan of Babylon Governorate, the directorate general of urban planning 2009. Information analysis report (Revised), Stage 2. Iraqi Ministry of Municipalities and Public Works, Baghdad, p 223

Iraqi Ministry of Oil (2015) Oil pipelines company, internal reports, Baghdad: Iraqi Ministry of oil limitations of oil and gas pipelines. Law No 40145 in 1989 
Iraqi Ministry of Planning (2013) Records of directorate of census Babylon, Internal Reports; Iraqi Ministry of Planning: Baghdad, Iraqi.

Iraqi Ministry of Planning (2017) Records of directorate of census Babylon, Internal Reports. Iraqi Ministry of Planning, Baghdad

Iraqi Ministry of Water Resources (1990) State Commission of Survey, Internal Reports. Iraqi Ministry of Water Resources, Baghdad

Iraqi Ministry of Water Resources (2015) General commission for groundwater, Internal reports. Iraqi Ministry of Water Resources, Baghdad

Ireland EPA (Ireland Environmental Protection Agency) (2000) Landfill manuals landfill site design, published by the Environmental Protection Agency, Ireland, pp. 154

Isalou A, Zamani V, Shahmoradi B, Alizadeh H (2013) Landfill site selection using integrated fuzzy logic and analytic network process (F-ANP). Environ Earth Sci 68:1745-1755

Jassim SZ, Goff JC (2006) Geology of Iraq. Dolin, Prague and Moravain museum, Brno, p 356

Javaheri H, Nasrabadi T, Jafarian MH, Rowshan GR, Khoshnam H (2006) Site selection of municipal solid waste landfills using analytical hierarchy process method in a geographical information technology environment in Giroft, Iran. J Environ Health Sci Eng 3: 177-184

Jin S, Yang L, Danielson P, Homer C, Fry J, Xian G (2013) A comprehensive change detection method for updating the national land cover database to circa 2011. Remote Sens Environ 132:159-175 http://digitalcommons.unl.edu/cgi/viewcontent.cgi?article= 1720\&context=usgsstaffpub. Access 16 December 2016

Kara C, Doratli N (2012) Application of GIS/AHP in siting sanitary landfill: a case study in Northern Cyprus. Waste Manag Res 30: 966-980

Kim KR, Owens G (2010) Potential for enhanced phytoremediation of landfills using biosolids: a review. J Environ Manag 91:791-797

Kontos TD, Komilis DP, Halvadakis CP (2003) Siting MSW landfills on Lesvos Island with a GIS based methodology. Waste Manag Res 21: 262-277

Lin H, Kao J (1999) Enhanced spatial model for landfill siting analysis. J Environ Eng 125:845-951

Moeinaddini M, Khorasani N, Danehkar A, Darvishsefat AA, Zienalyan M (2010) Siting MSW landfill using weighted linear combination and analytical hierarchy process (AHP) methodology in GIS environment (case study: Karaj). Waste Manag 30:912-920

Nas B, Cay T, Iscan F, Berktay A (2010) Selection of MSW landfill site for Konya, Turkey using GIS and multi-criteria evaluation. Environ Monit Assess 160:491-500

Ouma YO, Kipkorir EC, Tateishi R, MCDA-GIS Integrated Approach for Optimized Landfill Site Selection for Growing Urban Regions (2011) An application of neighbourhood proximity analysis. Ann GIS 17:43-62

Oweis IS, Khera RP (1998) Geotechnology of waste management, 2nd edn. PWS Publishing Company, Boston

Saaty TL (1980) The analytic hierarchy process. McGraw Hill, New York, NY, USA

Sadek S, El-Fadel M, Freiha F (2006) Compliance factors within a GISbased framework for landfill siting. Int J Environ Stud 63:71-86
Scott J, Beydoun D, Amal R, Low G, Cattle J (2005) Landfill management, leachate generation, and leach testing of solid wastes in Australia and overseas. Crit Rev Environ Sci Technol 35(3):239 332

Șener B (2004) Landfill site selection by using geography information system, Master Thesis, Middle East Technical University

Şener B, Suzen LM, Doyuran V (2006) Landfill site selection by using geographic information systems. Environ Geol 49:376-388

Șener Ș, Sener E, Karagüzel R (2011) Solid waste disposal site selection with GIS and AHP methodology: a case study in SenirkentUluborlu (Isparta) Basin, Turkey. Environ Monit Assess 173:533554

Sharifi MA, Retsios V (2004) Site selection for waste disposal through spatial multiple criteria decision analysis. J Telecommun Inf Technol $3: 1-11$

Sharifi M, Hadidi M, Vessali E, Mosstafakhani P, Taheri K, Shahoie S, Khodamoradpour M (2009) Integrating multi-criteria decision analysis for a GIS-based hazardous waste landfill sitting in Kurdistan Province, western Iran. Waste Manag 29:2740-2758

Siddiqui MZ, Everett JW, Vieux BE (1996) Landfill siting using geographic information systems: a demonstration. J Environ Eng 122: 515-523

Tagaris E, Sotiropoulou RP, Pilinis C, Halvadakis CP (2003) A methodology to estimate odors around landfill sites: the use of methane as an odor index and its utility in landfill siting. J Air Waste Manage Assoc 53:629-634

UNEP-IETC (2006) International Source Book on Environmentally Sound Technologies (ESTs) for Municipal Solid Waste Management (MSWM), http://www.unep.or.jp/Ietc/ESTdir/Pub/ MSW/index.asp. Accessed 20 February 2018

Uyan M (2014) MSW landfill site selection by combining AHP with GIS for Konya, Turkey. Environ Earth Sci 71:1629-1639

Wang G, Qin L, Li G, Chen L (2009) Landfill site selection using spatial information technologies and AHP: a case study in Beijing, China. J Environ Manag 90:2414-2421

World Digital Library (2013) The archaeological map of Iraq. Available online: http://www.wdl.org/en/item/212/. Accessed 24 September 2015

Worrell WA, Vesilind PA (2012) Solid waste engineering (2nd Edition), Cengage Learning. Stamford, USA (ISBN-13:978-1-4390-6215-9)

Yesilnacar MI, Cetin H (2008) An environmental geomorphologic approach to site selection for hazardous wastes. Environ Geol 55: $1659-1671$

Yildirim V (2012) Application of raster-based GIS techniques in the siting of landfills in Trabzon Province, Turkey: a case study. Waste Manag Res 30:949-960

Zeiss C, Lefsrud L (1995) Analytical framework for waste-facility siting. J Urban Plann Dev 121:115-145

Publisher's note Springer Nature remains neutral with regard to jurisdictional claims in published maps and institutional affiliations. 